\title{
A novel hybrid organosolv: steam explosion method for the efficient fractionation and pretreatment of birch biomass
}

Leonidas Matsakas ${ }^{1}$, Christos Nitsos ${ }^{1}$, Vijayendran Raghavendran ${ }^{2,4}$, Olga Yakimenko ${ }^{1}$, Gustav Persson, Eva Olsson ${ }^{3}$, Ulrika Rova', Lisbeth Olsson ${ }^{2}$ and Paul Christakopoulos ${ }^{1^{*}}$

\begin{abstract}
Background: The main role of pretreatment is to reduce the natural biomass recalcitrance and thus enhance saccharification yield. A further prerequisite for efficient utilization of all biomass components is their efficient fractionation into well-defined process streams. Currently available pretreatment methods only partially fulfill these criteria. Steam explosion, for example, excels as a pretreatment method but has limited potential for fractionation, whereas organosolv is excellent for delignification but offers poor biomass deconstruction.
\end{abstract}

Results: In this article, a hybrid method combining the cooking and fractionation of conventional organosolv pretreatment with the implementation of an explosive discharge of the cooking mixture at the end of pretreatment was developed. The effects of various pretreatment parameters (ethanol content, duration, and addition of sulfuric acid) were evaluated. Pretreatment of birch at $200{ }^{\circ} \mathrm{C}$ with $60 \% \mathrm{v} / \mathrm{v}$ ethanol and $1 \% \mathrm{w} / \mathrm{w}_{\text {biomass }} \mathrm{H}_{2} \mathrm{SO}_{4}$ was proven to be the most efficient pretreatment condition yielding pretreated solids with $77.9 \% \mathrm{w} / \mathrm{w}$ cellulose, $8.9 \% \mathrm{w} / \mathrm{w}$ hemicellulose, and $7.0 \mathrm{~W} / \mathrm{w}$ lignin content. Under these conditions, high delignification of $86.2 \%$ was demonstrated. The recovered lignin was of high purity, with cellulose and hemicellulose contents not exceeding 0.31 and $3.25 \% \mathrm{w} / \mathrm{W}$, respectively, and ash to be $<0.17 \% \mathrm{~W} / \mathrm{w}$ in all cases, making it suitable for various applications. The pretreated solids presented high saccharification yields, reaching $68 \%$ at low enzyme load (6 FPU/g) and complete saccharification at high enzyme load (22.5 FPU/g). Finally, simultaneous saccharification and fermentation (SSF) at 20\% w/w solids yielded an ethanol titer of $80 \mathrm{~g} / \mathrm{L}$ after $192 \mathrm{~h}$, corresponding to $90 \%$ of the theoretical maximum.

Conclusions: The novel hybrid method developed in this study allowed for the efficient fractionation of birch biomass and production of pretreated solids with high cellulose and low lignin contents. Moreover, the explosive discharge at the end of pretreatment had a positive effect on enzymatic saccharification, resulting in high hydrolyzability of the pretreated solids and elevated ethanol titers in the following high-gravity SSF. To the best of our knowledge, the ethanol concentration obtained with this method is the highest so far for birch biomass.

Keywords: Fractionation, Cellulose-enriched biomass, Hybrid organosolv-steam explosion, Birch, Ethanol, Highgravity, Inhibitor-free biomass, Delignification, Cellic CTec2

\footnotetext{
*Correspondence: paul.christakopoulos@|tu.se

${ }^{1}$ Biochemical Process Engineering, Division of Chemical Engineering, Department of Civil, Environmental, and Natural Resources Engineering, Luleå University of Technology, 971-87 Luleå, Sweden

Full list of author information is available at the end of the article
} 


\section{Background}

Valorization of lignocellulosic biomass from forestry, agricultural, or other industrial side streams for the production of energy, chemicals, and materials, has been the subject of intensive research over the past decades [1]. This interest is based on the fact that lignocellulose is an abundant, renewable, and sustainable resource that can be used as raw material in environmentally friendly and economically beneficial processes. The technologies available for the utilization of lignocellulose are dictated by its chemical composition and structure. With a composition of as high as $70 \%$ sugars in the form of cellulose and hemicellulose polymers [2, 3], lignocellulose represents the feedstock of a glucocentric biorefinery process, which was focused initially on production of bioethanol via fermentation of the glucose fraction. The natural recalcitrance of lignocellulose to enzymatic degradation has led to the development of pretreatment strategies that disrupt its complex structure allowing an increased saccharification yield [4]. A number of acidic, aqueous-based pretreatment methods, such as steam explosion [5], dilute acid [6], and hydrothermal [7] have been evaluated toward this direction. The primary goal of these methods is to remove the hemicellulosic barrier around cellulose, while also partly disrupting the lignocellulosic structure, in order to reduce biomass resistance to enzymatic saccharification. Steam explosion causes a dramatic disruption of biomass structure with immediate reduction of particle size and defibration of the substrate [8]. These physical effects, combined with the removal of hemicellulose, lead to enhanced enzymatic saccharification of even the toughest substrates such as softwoodderived biomass [9]. Consequently, steam explosion has been considered for many years as a state-of-the-art pretreatment method in bioethanol production. However, such glucocentric strategy has been marred by a combination of high process costs-particularly regarding the production of cellulolytic enzymes [10] - and relatively small profit margins afforded by bioethanol [11]. To improve profitability, the hemicellulosic sugar fraction has been used as a feedstock for cofermentation with cellulose, and hence to increase the overall ethanol yield [12]. At the same time, lignin - the third polymeric component of lignocellulosic biomass - has been utilized as a low-cost fuel for generating heat or electricity and thus bringing down the overall cost of the process [13]. A more resource-efficient approach would be to utilize the entire biomass in a biorefinery concept, where the different process streams can be directed toward a wide range of products [14]. In this view, all lignocellulose components are potential sources of value-added products.

Implementation of biorefinery concepts depends greatly on the efficiency of the fractionation technologies used to separate cellulose, hemicelluloses, and lignin, and how well-defined the resulting streams are [11]. This has led to a shift regarding the role of lignin. In typical second-generation bioethanol production processes, lignin has been collected as a low-value byproduct and used for cogeneration of heat or electricity. However, when targeting added values from all biomass components, production of a high-purity lignin stream becomes a new necessity; especially since the phenolic components of lignin have been identified as a platform for the production of a variety of chemicals and polymers [15]. A comprehensive strategy for isolating lignin in the first step of the pretreatment/fractionation process is paramount to achieve a high-purity lignin-stream [16]. The requirement for 'lignin-first' removal is enhanced by the fact that lignin negatively affects the enzymatic saccharification of cellulose. This negative influence is the result of irreversible adsorption of cellulolytic enzymes onto lignin, and causes physical blockage of the enzymes on cellulose chains, as well as the inhibition of cellulolytic enzymes by soluble lignin-derived molecules [17]. Therefore, lignin removal during the first process step does not only provide a cleaner lignin stream, but can also improve the economics of traditional fermentation-based bioethanol processes as lignin can be used in high-value-added applications [18]. Organosolv pretreatment/fractionation represents one of the most promising biomass delignification and fractionation methods within the biofuels and biorefinery context $[19,20]$. In the organosolv pretreatment/fractionation, biomass is heated up to a temperature range of $100-250{ }^{\circ} \mathrm{C}$ in an aqueous-organic solvent solution [21] for a specified duration resulting in three fractions: a solid dry lignin, an aqueous hemicellulose fraction, and a cellulose-rich solid fraction [22]. Low molecular weight aliphatic alcohols, such as ethanol, are frequently used as the organic solvent as they are easy to be recovered by distillation at the end of the organosolv and re-used in subsequent treatments $[18,23]$. Implementation of such pretreatment/fractionation technologies is expected to facilitate the coexistence of traditional fermentation-based technologies with novel processes for the utilization of hemicellulose and lignin in broader biorefinery concepts, thus allowing for a multitude of products and higher profit margins [11]. It was previously shown that organosolv treatment and steam explosion pretreatment could be combined in a sequential way for the pretreatment of wheat straw [24] and fescue [25]; however, this significantly increases the process complexity (e.g., multiple stages of heating/cooling cycles and increased total process time).

The main aim of the current study was to develop a novel pretreatment method allowing for efficient fractionation of lignocellulosic biomass into cellulose, 
hemicellulose, and lignin streams. At the same time, the improved pretreatment method should be able to allow for high enzymatic saccharification yields of the cellulose stream for use in biochemical conversion processes. To attain this goal, we combined the fractionation efficiency of conventional organosolv processes with the benefit of physical biomass size reduction achieved during steam explosion into a single stage process. The suggested process was performed in a horizontal design steam explosion reactor, modified to also operate as an organosolv cooking vessel, as shown previously [26]. The novel method was carried out with an explosive discharge of the reactor's content after conventional ethanol organosolv cooking. Process parameters such as time, ethanol content, and the addition of acid catalyst were studied for the effective pretreatment and fractionation of a representative hardwood biomass (birch). The effect of the explosion step on enzymatic saccharification of cellulose was also investigated. Finally, the ability of the proposed method to produce a cellulose-rich solid fraction that could effectively be saccharified and used during a biochemical conversion method was tested during highgravity ethanol fermentation.

\section{Results and discussion}

Evaluation of fractionation efficiency of the hybrid method Effect on biomass solubilization and composition

\section{of the pretreated solids}

In our previous work on conventional batch organosolv fractionation of biomass [19], a pretreatment temperature of $182{ }^{\circ} \mathrm{C}$ for $60 \mathrm{~min}$ resulted in a $69 \%$ removal of lignin from birch biomass. To improve the performance of the hybrid organosolv method, a higher pretreatment temperature, $200{ }^{\circ} \mathrm{C}$, was selected, and the effects of cooking time, ethanol content, and sulfuric acid concentration in the pretreatment liquor, in the presence of the explosive discharge step, were investigated. The effects of these parameters on the overall solubilization of birch biomass, the composition of the pretreated solids, and the solubilization of the major biomass component (cellulose, hemicellulose, and lignin) are summarized in Table 1. The aim of pretreatment was to obtain a solid material with high cellulose content and low hemicellulose and lignin content.

A reduction of ethanol content from 70 to $50 \% \mathrm{v} / \mathrm{v}$ during constant treatment led to an increase in biomass solubilization from 41.5 to $48-49 \%$ (calculated as the dry-mass fraction recovered as pretreated solids). This increase could be explained by the increased chemical hydrolysis of carbohydrates, and possible cleavage of $\alpha$ and $\beta$-ether bonds of lignin [27], caused by the higher water content and its increased chemical activity in the pretreatment liquor. Reduced ethanol content in the pretreatment liquor also had a positive effect on cellulose level, which increased from $61.7 \%$ at $70 \% \mathrm{v} / \mathrm{v}$ ethanol to $65.9 \%$ at $50 \%$ ethanol and was accompanied by a reduction in hemicellulose content from 21.9 to $15.1 \%$. Cellulose solubilization during pretreatment was not affected by the varying ethanol concentration employed (Table 1) and cellulose was completely recovered in the pretreated solid. Hemicellulose solubilization increased from 59 to 66 and $75 \%$ as ethanol decreased from 70 to 60 and $50 \%$, respectively (Table 1 ). The latter had also a positive impact on delignification (Table 1). A similar trend had been observed during organosolv treatment of wheat straw, where delignification decreased from 38.8 to $20.8 \%$ when ethanol content increased from 50 to $80 \% \mathrm{w} / \mathrm{w}$ [28]. Increased delignification with decreasing ethanol content is a consequence of the higher chemical activity of water, resulting in the cleavage of ether linkages and concomitant lignin fragmentation $[27,29]$.

Table 1 Composition of pretreated solids at different pretreatment conditions

\begin{tabular}{|c|c|c|c|c|c|c|}
\hline \multicolumn{3}{|c|}{ Pretreatment conditions } & \multirow{2}{*}{$\begin{array}{l}\begin{array}{l}\text { Biomass solubilization } \\
\text { (\% of initial biomass) }\end{array} \\
47.9\end{array}$} & \multirow{2}{*}{$\begin{array}{l}\text { Cellulose (\% w/w) } \\
65.9(1.2 \%)\end{array}$} & \multirow{2}{*}{$\begin{array}{l}\begin{array}{l}\text { Hemicellulose } \\
\text { (\% w/w) }\end{array} \\
15.1(74.8 \%) \\
\end{array}$} & \multirow{2}{*}{$\begin{array}{c}\text { Lignin (\% w/w) } \\
6.7(81.2 \%)\end{array}$} \\
\hline Ethanol effect & $30 \mathrm{~min}$ & $50 \% \mathrm{v} / \mathrm{v}$ & & & & \\
\hline & & $60 \% \mathrm{v} / \mathrm{v}$ & 48.9 & $67.1(1.3 \%)$ & $21.0(65.7 \%)$ & 7.1 (80.5\%) \\
\hline & & $70 \% \mathrm{v} / \mathrm{v}$ & 41.5 & $61.7(0.0 \%)$ & $21.9(59.0 \%)$ & $8.7(72.6 \%)$ \\
\hline \multirow[t]{3}{*}{ Time effect } & $60 \% \mathrm{v} / \mathrm{v}$ & $15 \min$ & 44.7 & $66.3(0.0 \%)$ & $22.0(61.1 \%)$ & $7.8(77.0 \%)$ \\
\hline & & $30 \mathrm{~min}$ & 48.9 & $67.1(1.3 \%)$ & $21.0(65.7 \%)$ & $7.1(80.5 \%)$ \\
\hline & & $60 \mathrm{~min}$ & 40.0 & $60.7(0.0 \%)$ & $19.1(63.4 \%)$ & $13.2(57.5 \%)$ \\
\hline \multirow[t]{3}{*}{ Catalyst effect } & $15 \mathrm{~min}-60 \% \mathrm{v} / \mathrm{v}$ & $0 \%$ & 44.7 & $66.3(0.0 \%)$ & $22.0(61.1 \%)$ & $7.8(77.0 \%)$ \\
\hline & & $0.2 \%$ & 45.0 & $61.1(3.2 \%)$ & $25.8(54.5 \%)$ & $7.4(78.2 \%)$ \\
\hline & & $1 \%$ & 63.1 & $77.9(17.2 \%)$ & 8.9 (89.5\%) & 7.0 (86.2\%) \\
\hline
\end{tabular}

All results are expressed based on dry mass. Numbers in parenthesis represent the mass fraction of each component (i.e., cellulose, hemicellulose, and lignin) that was solubilized at the end of the pretreatment (calculated using Eq. 1). Compositional analysis was performed in duplicates, and the standard error was $>5 \%$ of the value. All the trials were done with the explosive discharge step at the end of the treatment 
An ethanol content of $60 \% \mathrm{v} / \mathrm{v}$ was used to evaluate the effect of cooking time. Increasing cooking time from 15 to $30 \mathrm{~min}$ had a positive impact on biomass solubilization, whereas a further increase to $60 \mathrm{~min}$ had a negative effect (Table 1). Moreover, increasing the treatment time from $15-30$ to $60 \mathrm{~min}$ led to a drop in cellulose content in the pretreated solids from $66-67$ to $61 \% \mathrm{w} / \mathrm{w}$, respectively (Table 1 ), even though no cellulose solubilization was observed during the pretreatment. Prolonged pretreatment time $(60 \mathrm{~min})$ resulted in a higher lignin content and a decreased delignification of the materials, possibly due to the formation of pseudo-lignin [30, 31], as well as lower hemicellulose content in the solid fraction and increased hemicellulose solubilization. Formation of insoluble lignin-like compounds or pseudo-lignin (mainly from the hemicellulose decomposition) is well documented in the literature, and these compounds are normally measured as lignin content, thus increasing the determined lignin content in the pretreated solids [32-34]. The decrease in solubilization under harsher pretreatment conditions could also be attributed to the formation of the pseudo-lignin.

Using the 15-min treatment as a reasonable compromise between time and efficiency, addition of an acidic catalyst (sulfuric acid) on pretreatment efficiency was examined. Addition of the catalyst at $0.2 \% \mathrm{w} / \mathrm{w}$ of biomass had almost no impact on the overall biomass solubilization, whereas a $1 \% \mathrm{w} / \mathrm{w}$ catalyst concentration increased biomass solubilization to $63 \%$, mainly due to extensive cleavage of carbohydrates and aryl-ether bonds of lignin [35,36]. Addition of $1 \% \mathrm{w} / \mathrm{w}$ acid catalyst resulted in very high cellulose content (78\%) and increased solubilization of hemicellulose (Table 1), with part of the cellulose being solubilized due to the acid. In contrast, addition of $0.2 \%$ acid catalyst did not improve hemicellulose solubilization compared to pretreatment without catalyst. The same trend was observed for delignification: at the lower concentration the catalyst had only a minor positive impact, whereas at the higher concentration delignification increased from 77 to $86 \%$ (Table 1). The extended solubilization of hemicellulose and lignin is a result of the severe conditions during the pretreatment caused by the higher acid concentration.

In general, the novel pretreatment system resulted in pretreated solids with high cellulose content. Hemicellulose was resilient to all pretreatment conditions and its content in the pretreated solids was relatively high (Table 1). Indeed, with the exception of the high-concentration acid catalyst pretreatment (where $89.5 \%$ of the initial hemicellulose solubilized), the percentage of hemicellulose solubilization was between 54.5 and $74.8 \%$ of the initial hemicellulose fraction (Table 1). The main advantage of the proposed pretreatment method when using birch biomass was its effective lignin removal. Specifically, lignin content of the pretreated solids was below $9 \%$ in most cases, and dropped to $7 \%$ when $1 \%$ acid was used. Such highly efficient delignification, combined with elevated cellulose content in some pretreated solids, is very promising not only as a biomass fractionation method, but also for effective and low-cost enzymatic hydrolysis of pretreated solids [17]. In addition, high cellulose content is necessary to achieve high ethanol titers in bioethanol production.

\section{Lignin purity}

As discussed before, the hybrid pretreatment method developed here resulted in a process with delignification yields as high as $86 \%$ (as calculated with the Eq. 1). Besides the yield, the percentage of impurities (e.g., cellulosic and hemicellulosic sugars and ash) in the recovered lignin is also important when considering the utilization of lignin in a biorefinery to produce fuels, chemicals, or materials. The carbohydrate and inorganic ash contents of the different lignin fractions are presented in Fig. 1. Lignin purity remained high throughout the whole range of pretreatment conditions evaluated. Ash content was minimal and did not exceed $0.17 \% \mathrm{w} / \mathrm{w}$; and the cellulose content remained low, between $0.11 \%$ and $0.31 \% \mathrm{w} / \mathrm{w}$. Hemicellulose sugars were slightly higher, but they never exceeded 3.25\%; the lowest carbohydrate content was obtained with $1 \%$ sulfuric acid. Overall, purity of $>96 \%$ was achieved in all samples, thus offering a very efficient fractionation of high-quality lignin. High purity and low ash content (especially low sulfur content) are unique qualities of organosolv lignin compared to Kraft pulping [37]. Due to the efficient delignification by the novel hybrid pretreatment method, lignin depositions on the biomass were not observed (see "Assessing the role of explosive discharge" section).

\section{Sugar composition in the liquid fraction}

Figure 2 shows the sugar composition of the aqueous liquid fraction of the pretreated liquor following separation from the solids by vacuum filtration, ethanol evaporation, and lignin recovery. Some of the sugars removed from the biomass during pretreatment were recovered in the pretreatment liquor as a mixture of monomers and oligomers (or soluble polysaccharides). Monomeric sugars of cellulosic origin were relatively low, with glucose detected only in the sample treated with $0.2 \%$ acid catalyst; oligomeric glucose accounted for up to $3.1 \%$ of the cellulose in untreated biomass. Sugars originating from hemicellulose were more abundant, owing to extensive hemicellulose hydrolysis during pretreatment. The concentration of ethanol used in the pretreatment step affected the total amount of hemicellulosic sugars 


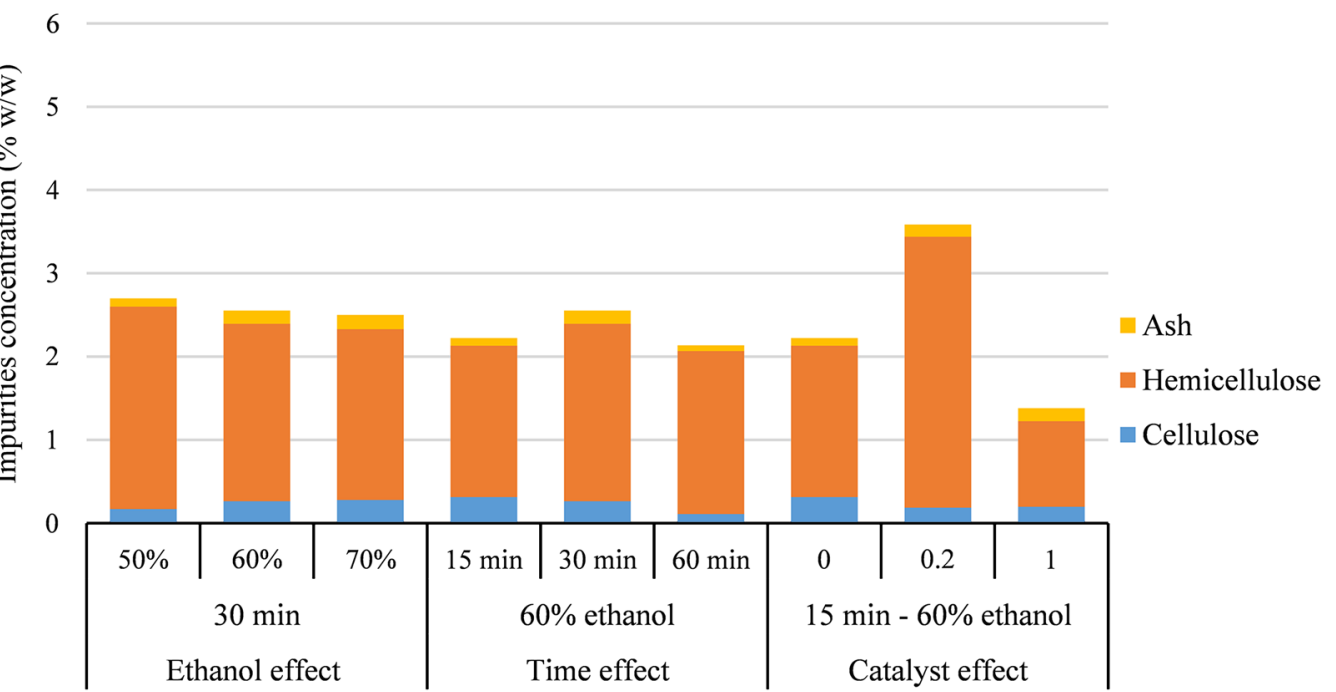

Fig. 1 Carbohydrate and ash contents in the lignin fraction obtained under different treatment conditions with birch biomass. The analysis was done in duplicates
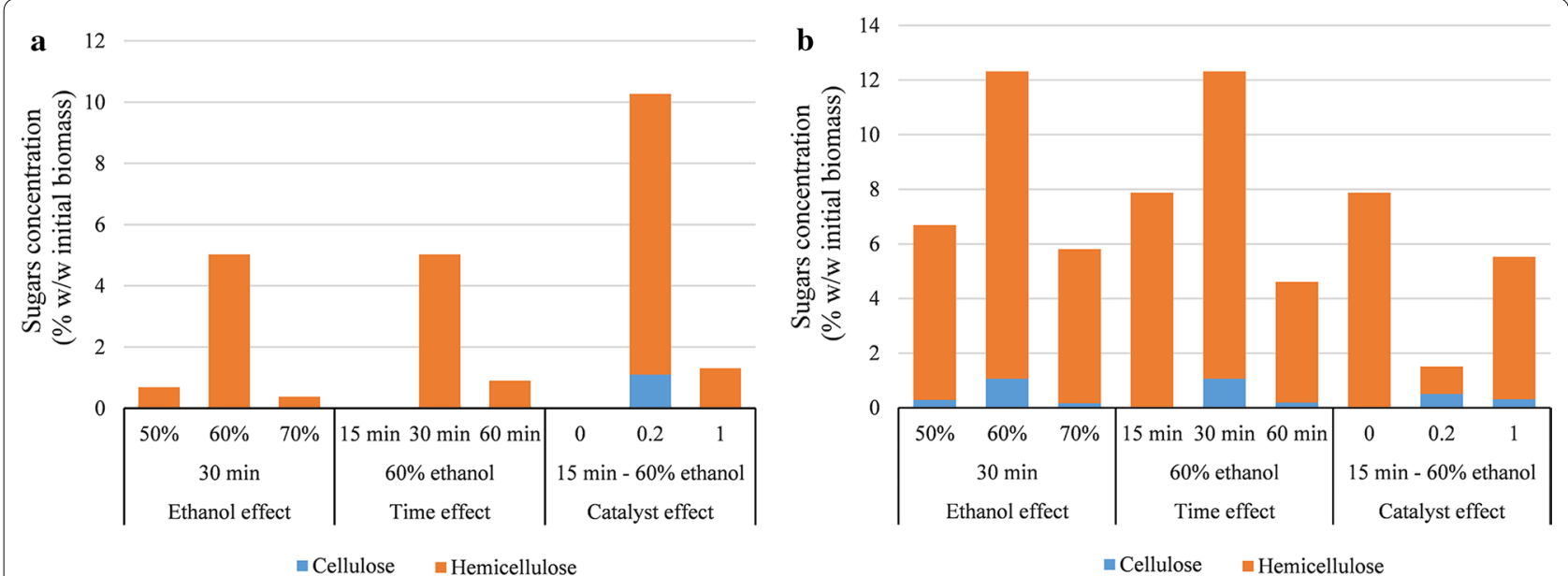

Fig. 2 Composition of cellulose and hemicellulose sugars in the liquid fraction after lignin recovery in the form of sugar monomers (a) and oligosaccharides (b). The analysis was done in duplicates

(both monomeric sugars and oligomers), with the highest concentration obtained with $60 \%$ ethanol (Fig. 2). A similar trend was also observed during the pretreatment of wheat straw with acetone-water mixtures, where increasing the solvent content to $40 \% \mathrm{v} / \mathrm{v}$ increased the concentration of hemicellulosic sugars in the liquor, but any further increase had a negative impact on the concentration of the hemicellulosic sugars in the liquor [38]. When treatment time was increased, the concentration of hemicellulosic sugars in the pretreated liquor initially increased, but decreased when the treatment was extended to $60 \mathrm{~min}$, possibly due to the degradation of the monomeric sugars as a result of prolonged heating.
This finding correlates well with the results of biomass solubilization (which decreased with prolonged treatment time) and the hemicellulose and lignin contents in pretreated biomass (Table 1 ). Finally, a $0.2 \% \mathrm{w} / \mathrm{w}$ addition of acid catalyst increased the concentration of sugars in the pretreated liquor (Fig. 2); however, sugar recovery decreased with $1 \%$ acid, possibly because of accelerating sugar degradation reactions [7].

Apart from hemicellulosic sugars in the liquor, treatment conditions affected also the ratio between monomeric and oligomeric sugars. In general, sugars found in monomeric form were lower compared to oligomers; only when $0.2 \%$ sulfuric acid was used as a catalyst 
were monomeric sugars approximately nine times more abundant than oligomers. Ethanol content had a minor impact on the ratio between monomeric and oligomeric sugars: it increased initially when ethanol rose from 50 to $60 \%$, but decreased thereafter, probably due to the lower water content and therefore lower generation of hydronium ions that can selectively depolymerize hemicellulose [39]. A short treatment time of 15 min yielded only oligomeric hemicellulosic sugars, whereas a 30-min treatment increased the amount of monomeric sugars in the liquor. Notably, the ratio between monomeric and oligomeric sugars declined when treatment time was prolonged to $60 \mathrm{~min}$, probably due to extended decomposition of hemicellulosic sugars as sugars of hemicellulosic origin (especially xylose) are generally sensitive to thermal degradation under harsher pretreatment conditions [40]. Finally, the addition of acidic catalyst initially increased the ratio of monomeric sugars due to the more acidic conditions created that promoted the depolymerization of oligomeric sugars, whereas, at the highest concentration of $1 \% \mathrm{w} / \mathrm{w}$, the amount of monomeric sugars was considerably reduced. Recovery of the hemicellulosic sugars in the liquid fraction after the organosolv pretreatment has been found to be significantly dependent on the concentration of the acid catalyst employed as increasing the acid catalyst decreased the recovery [41].

\section{Evaluation of saccharification efficiency of pretreated solids}

Apart from achieving good fractionation yields, one important aspect of establishing a pretreatment process is to produce pretreated solids that present high saccharification yields. High glucose concentration is very important for the subsequent bioconversion processes, such as ethanol fermentation, as it can result in high product titers. Therefore, the first step to assess the potential of the pretreated solids prior to bioconversion is to assess their saccharification yields. For this reason, we performed enzymatic saccharification trials at low solids content aiming to select the materials with high saccharification yields and subsequently evaluate them as raw materials for ethanol production.

Figure 3a shows the effect of ethanol, treatment time, or acid addition during the pretreatment on the saccharification yields (as defined in Eq. 2) during enzymatic hydrolysis of the pretreated solids. Increasing the acid catalyst concentration had a significant effect on saccharification yield, which increased from 43 to $68 \%$. Instead, increasing treatment time had only a moderate effect, resulting to a saccharification yield of 42,51 , and $58 \%$ for 15,30 , and $60 \mathrm{~min}$, respectively, in spite of a reduced delignification yield achieved at 60 min treatment. In contrast, increasing the ethanol concentration to $70 \%$ during pretreatment decreased saccharification yield (from 51 to 43\%) and delignification (see "Effect on biomass composition and delignification" section). To further examine the effect of acid catalyst addition on saccharification yield, birch biomass treated with and without acid catalyst was tested under various enzyme dosage conditions (Fig. 3b). Presence of acid catalyst during pretreatment increased the saccharification yield at all enzyme loadings tested during the current work. The most profound improvement, however, was observed at the lower enzyme load of $6 \mathrm{FPU} / \mathrm{g}$ of enzyme preparation, with an increase in the saccharification yield of $63 \%$ compared to birch treated without the addition of acid catalyst. The difference in the saccharification yields between the two pretreated materials decreased with the increasing enzyme dosage,
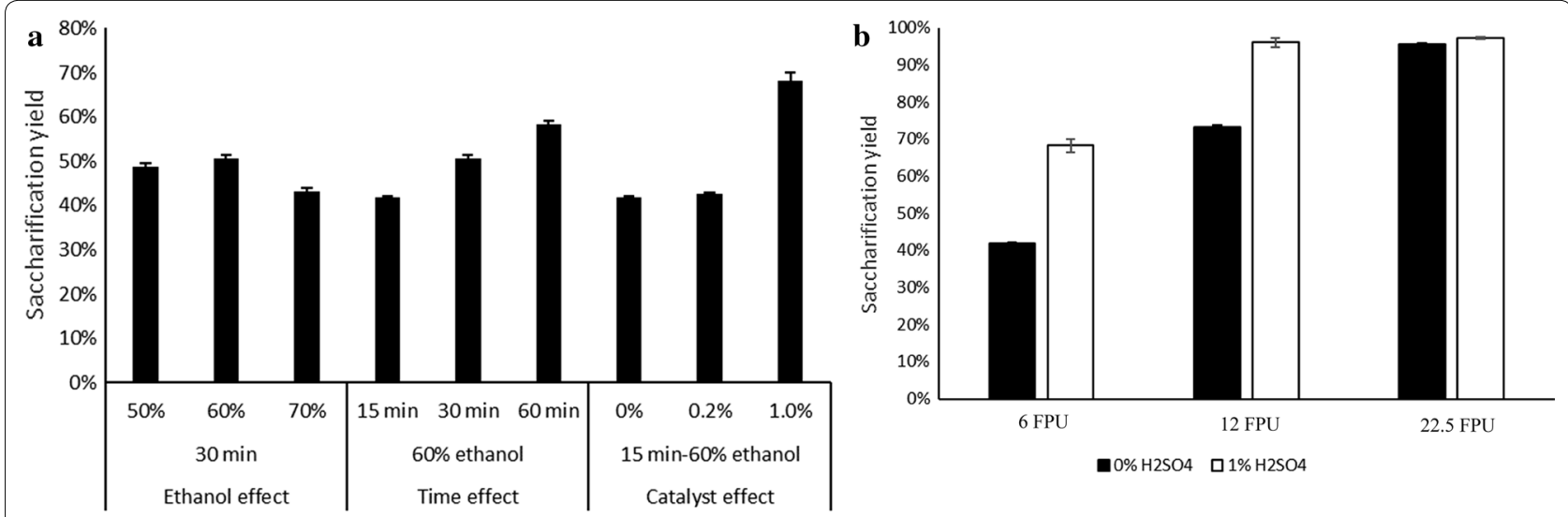

Fig. 3 Effects of pretreatment parameters on the enzymatic saccharification of the pretreated solids under a constant enzyme load of 6 FPU/ $g_{\text {solids }}$ at a solid loading of $2 \%$ (a). Effects of different enzyme loadings on the saccharification yields with and the without the addition of $1 \%$ sulfuric acid for the pretreatment taking place with $60 \%$ ethanol for $15 \mathrm{~min}$ (b). The saccharification yield calculated based on the cellulose content in the pretreated solids 
and, indeed, identical yields were reached at the higher enzyme dosage tested, where saccharification was almost complete. Accordingly, addition of acid catalyst enables the use of a lower enzyme dosage. Besides enhanced saccharification yield, catalyst addition resulted in a material with higher cellulose content than when no acid catalyst was added ( $78 \%$ compared to $66 \%$-Table 1$)$, which in turn led to higher glucose concentration in the broth.

The material treated under optimal conditions $(60 \% \mathrm{v} / \mathrm{v}$ ethanol, $15 \mathrm{~min}, 1 \% \mathrm{w} / \mathrm{w} \mathrm{H}_{2} \mathrm{SO}_{4}$ ) with the newly developed method outperformed the material treated with steam explosion (Figs. 3 and 4). More specifically, the saccharification yields were 68,97 , and $100 \%$ for 6,12 , and $22.5 \mathrm{FPU} / \mathrm{g}$ enzyme load, respevtively (Fig. 3b). In contrast, the saccharification yields obtained from the material pretreated with steam explosion were 46, 69 and $83 \%$, respectively. Furthermore, due to the difference in cellulose composition, the hybrid pretreated material yielded 590, 830, and $843 \mathrm{mg}_{\text {glucose }} / \mathrm{g}$ for enzyme loadings of 6,12 , and $22.5 \mathrm{FPU} / \mathrm{g}$, respectively. The glucose yields for the steam exploded materials were 292, 437, and $529 \mathrm{mg}_{\text {glucose }} / \mathrm{g}$, respectively, for the same enzyme loadings. This difference in the glucose concentration is very important for the subsequent microbial conversion processes such as ethanol fermentation.

\section{Assessing the role of explosive discharge}

What differentiates the proposed hybrid solvent organosolv-steam explosion pretreatment approach from more conventional organosolv methods is the combination of solvent cooking with the explosive discharge at the end of pretreatment. This step was applied in an effort to combine the fractionation efficiency of organosolvtype treatments with the positive effect of explosion on enzymatic saccharification, as observed in conventional steam explosion [42]. To evaluate the effect of explosion on enzymatic saccharification of the solids, experiments without explosive discharge were performed (the chosen conditions were $60 \% \mathrm{v} / \mathrm{v}$ ethanol for $15 \mathrm{~min}$ without addition of acidic catalyst). The reason to perform the evaluation of the explosive discharge without the use of the acid catalyst was to study the effect of the explosion 'independently' without the additive effect of the acid catalyst. Moreover, steam pretreatment experiments with and without explosion (see "Methods" section) were also performed to compare the proposed hybrid process in terms of pretreatment efficiency with a state-of-the-art pretreatment method.

The chemical composition of pretreatment solids from these experiments is presented in Table 2. For organosolv pretreatment, explosion increased the content of cellulose and hemicellulose on the resulting solid fraction, whereas the content of lignin was slightly decreased. Instead, in steam explosion trials, hemicellulose and lignin were not affected, whereas the non-exploded material presented reduced cellulose content. Next, the effect of the explosive discharge on enzymatic saccharification of treated solids was evaluated for a range of enzyme loadings. Addition of the explosive discharge to traditional organosolv cooking had a positive impact on enzymatic saccharification yield at all tested enzyme loadings

Table 2 Effect of explosive discharge on the composition of pretreated solids

\begin{tabular}{|c|c|c|c|}
\hline $\begin{array}{l}\text { Pretreatment } \\
\text { conditions }\end{array}$ & $\begin{array}{l}\text { Cellulose } \\
(\% \mathrm{w} / w)\end{array}$ & $\begin{array}{l}\text { Hemicellulose } \\
(\% \mathrm{w} / \mathrm{w})\end{array}$ & Lignin (\% w/w) \\
\hline \multicolumn{4}{|c|}{ Organosolv $\left(200^{\circ} \mathrm{C}-60 \%\right.$ v/v ethanol $\left.-15 \mathrm{~min}\right)$} \\
\hline With explosion & 66.3 & 22.0 & 7.8 \\
\hline Without explosion & 57.7 & 17.4 & 9.1 \\
\hline \multicolumn{4}{|c|}{ Steam explosion $\left(200^{\circ} \mathrm{C}-5 \mathrm{~min}-0.14 \% \mathrm{w} / \mathrm{w} \mathrm{H}_{2} \mathrm{SO}_{4}\right)$} \\
\hline With explosion & 57.2 & 12.1 & 27.1 \\
\hline Without explosion & 46.8 & 13.0 & 27.7 \\
\hline
\end{tabular}

Compositional analysis was performed in duplicates
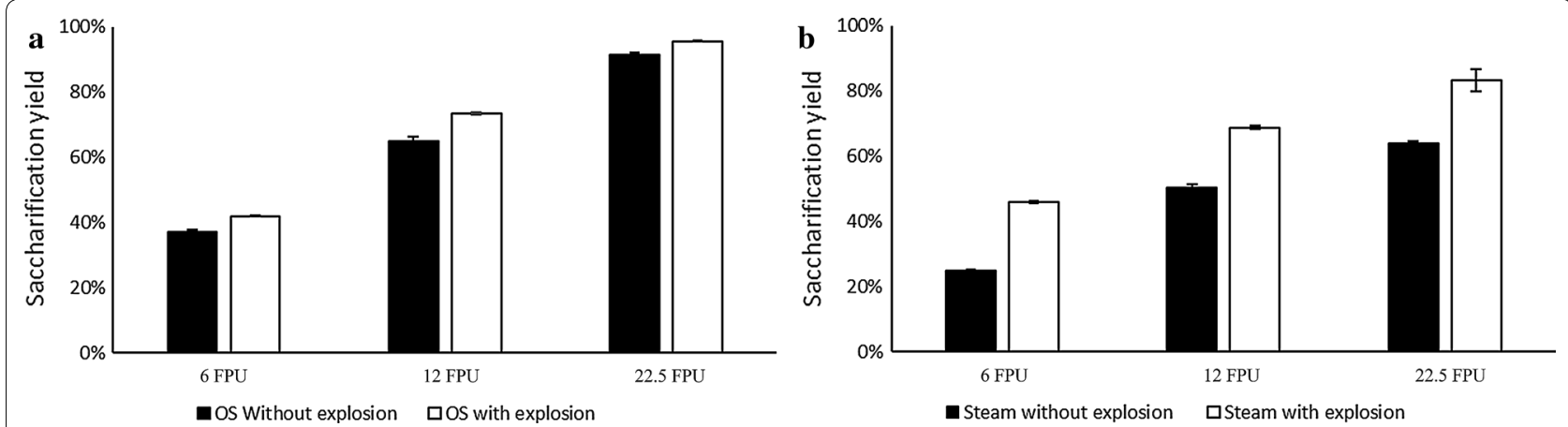

Fig. 4 Effect of enzyme dosage on OS (organosolv) samples with and without explosion (a); effect of enzyme loading on birch pretreated with steam explosion with and without the explosive discharge (b) 
(Fig. 4a). This improvement ranged from 4.5 to $13.5 \%$, with the highest gain observed at the lowest enzyme load tested. To better understand the effect of the explosion on enzymatic saccharification of cellulose, the same trial took place with steam explosion pretreatment with or without the explosion step. Again, similar to organosolv treatment, the presence of the explosion at the end of the cooking time significantly improved saccharification yields (Fig. 4b); although the explosion step had a much greater impact compared to the effect on the organosolv. The same positive effect of the explosive discharge on enzymatic saccharification had been reported also for steam explosion-pretreated spruce, corn stover, and beech wood [43, 44]. However, to the best of our knowledge, this is the first time that the effect of the explosive discharge was applied and studied in combination with organosolv cooking. The enzymatic saccharification results were corroborated by observation of the solids' morphology by SEM (Fig. 5). When the explosive discharge was included at the end of pretreatment, the pretreated fibers appeared smaller and less intact compared to when the explosive discharge was omitted (Fig. 5). Moreover, in the absence of the explosive discharge step, the surface of pretreated fibers seemed smoother and without any significant damage. Similar morphological changes were also observed in the explosive discharge step during the pretreatment of spruce chips [44]. Finally, in contrast to steam explosion, where lignin droplets are deposited on the surface of the biomass, pretreatment with the hybrid process did not result in any lignin deposition (Fig. 5-refer to high magnification images).
Although organosolv pretreatment with explosion exhibited only a moderate effect on the saccharification yield compared to the non-exploded, the difference in glucose released per gram of substrate was actually larger owing to a considerably higher cellulose content in the pretreated fibers when explosion was included compared to when it was absent $(66 \% \mathrm{w} / \mathrm{w}$ vs $58 \% \mathrm{w} / \mathrm{w})$.

\section{Ethanol fermentation with pretreated solids}

Finally, the fermentation potential of pretreated solids was examined under both low- and high-gravity conditions. Initially, fermentability of the pretreated solids was assessed on birch pretreated under the two conditions that yielded the highest saccharification (Fig. 3a): 60\% ethanol with $1 \%$ acid catalyst for $15 \mathrm{~min}$, and $60 \%$ ethanol for $60 \mathrm{~min}$. The ethanol thus obtained reached 21 and $8 \mathrm{~g} / \mathrm{L}$, respectively (Fig. 6a), corresponding to yields equal to 100 and $50 \%$ of the maximum theoretical value (based on the cellulose content of the pretreated solids). Despite the excellent yields obtained during low-gravity fermentation, the obtained ethanol titers were lower compared to the minimum requirements $-40 \mathrm{~g} / \mathrm{L}-$ for an economically feasible large-scale ethanol distillation [45]. A trend in second-generation ethanol production is to move toward higher gravity to reach more cost effective processes, with higher ethanol titers, better water economy, and more efficient processing [46]. Based on the results obtained from the low-gravity trials, acid-pretreated solids were used for high-gravity fermentation. The initial concentration of solids was rather high, $20 \% \mathrm{w} / \mathrm{w}$, which posed a challenge for the proper mixing of the

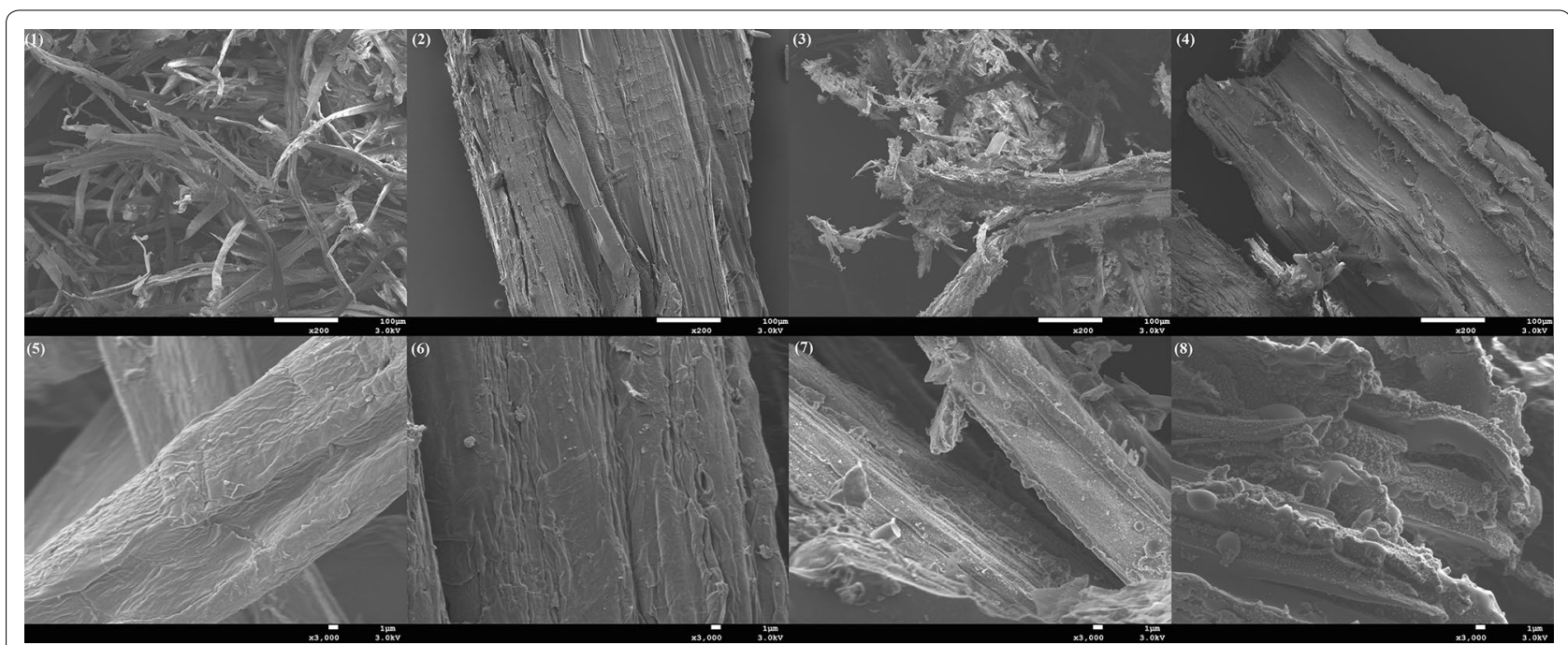

Fig. 5 SEM imaging at low (1-4) and high (5-8) magnifications of birch treated with hybrid organosolv pretreatment, with $(1,5)$ and without $(2,6)$ the presence of explosive discharge at the end of the pretreatment and treated with traditional steam explosion with $(3,7)$ and without $(4,8)$ the presence of explosive discharge at the end of the pretreatment 

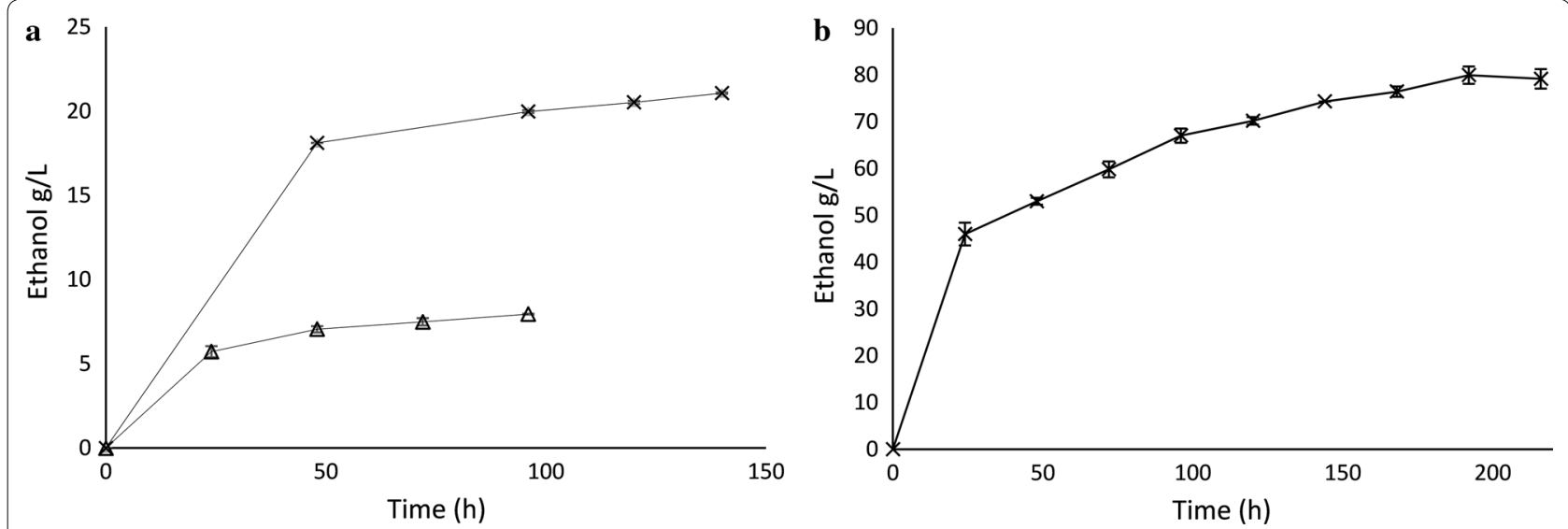

Fig. 6 Ethanol profile during SSF with hybrid organosolv-pretreated birch biomass, (a) at 5\% w/w solids loading with (cross) or without acid (triangle) catalyst, and (b) at 20\% w/w loading with acid catalyst

material. To overcome this problem, a previously established gravimetric saccharification reactor [47-49] was used for $8 \mathrm{~h}$ prehydrolysis. After the prehydrolysis step, the concentration of glucose in the slurry reached $81 \mathrm{~g} / \mathrm{L}$, corresponding to a saccharification yield of $47 \%$ of the glucan. The high glucose concentration at the beginning of fermentation is a very promising characteristic for the subsequent fermentation step, thereby demonstrating the potential of the pretreated birch biomass. Indeed, ethanol production began rapidly, reaching $46 \mathrm{~g} / \mathrm{L}$ after only $24 \mathrm{~h}$, with a volumetric productivity of $1.9 \mathrm{~g} / \mathrm{L}$ h, surpassing the $40 \mathrm{~g} / \mathrm{L}$ threshold. Thereafter, ethanol productivity diminished compared to the initial $24 \mathrm{~h}$; however, ethanol was produced at a significant rate even after $192 \mathrm{~h}$ of fermentation. The highest concentration obtained during this work was $80 \mathrm{~g} / \mathrm{L}$, corresponding to a yield of $90 \%$ of the theoretical maximum (Fig. 6b). To the best of our knowledge, this is the highest reported ethanol concentration obtained from birch biomass (Table 3), demonstrating the superiority of the proposed hybrid pretreatment method. Also, the ethanol concentration reached in this work was among the highest reported for woody biomass (Table 3). Our novel hybrid solvent organosolv-steam explosion pretreatment method offers a superior solution to the pretreatment of woody biomass, resulting in an inhibitor-free pretreated material that is easily hydrolyzable and yielding high sugar titers at highsolid loadings.

\section{Conclusions}

Efficient and complete utilization of forest biomass for the production of portfolio of products including renewable fuels such as ethanol, requires the development of a novel biorefinery concept capable of utilizing each biomass component. To achieve this, new fractionation technologies need to be developed. In the present study, we propose a novel hybrid pretreatment/fractionation method that combines the

Table 3 Ethanol production reported in the literature for high-gravity fermentation of various wood lignocellulosic raw materials

\begin{tabular}{|c|c|c|c|c|c|c|c|}
\hline WIS (\%) & Material & Pretreatment & Strain & Enzyme loading & Ethanol (g/L) & Time (h) & References \\
\hline 20 & Birch & Steam pretreated & KE6-12 & $20 \mathrm{FPU} / \mathrm{g}$ & 14.4 & 144 & [50] \\
\hline 20 & Spruce & Steam pretreated & Thermosacc Dry & $22.5 \mathrm{FPU} / \mathrm{g}$ & 40 & 96 & [51] \\
\hline 15 & Eucalyptus & Organosolv & IR2-9a & $20 \mathrm{FPU} / \mathrm{g}$ & 42 & 72 & {$[52]$} \\
\hline 10 & Spruce & Steam pretreated & TMB3400 & $30 \mathrm{FPU} / \mathrm{g}$ glucan & 45 & 100 & [53] \\
\hline 10 & Spruce & Steam pretreated & Ethanol Red & $20 \mathrm{FPU} / \mathrm{g}$ & 45.8 & 96 & {$[54]$} \\
\hline 25 & Pine & Sulfite & $\begin{array}{l}\text { S. cerevisiae from } \\
\text { Angel Yeast Co. } \\
\text { Ltd }\end{array}$ & $15 \mathrm{FPU} / \mathrm{g}$ & 82 & 24 & {$[55]$} \\
\hline 20 & Beechwood & Acetone/water oxidation & Ethanol Red & 8.4 FPU/g & 75.9 & 120 & {$[56]$} \\
\hline 20 & Eastern red cedar & Acid bisulfite & $\mathrm{D}_{5} \mathrm{~A}$ & $46 \mathrm{FPU} / \mathrm{g}$ glucan & 52 & 42 & [57] \\
\hline 20 & Birch & Hybrid organosolv—steam explosion & Ethanol Red & $18.5 \mathrm{FPU} / \mathrm{g}$ & 80 & 192 & This study \\
\hline
\end{tabular}


fractionation efficiency of traditional organosolv processes with the explosive discharge at the end of pretreatment. Optimization of pretreatment parameters resulted in $86 \%$ delignification and pretreated solids with high cellulose (78\%) and low lignin (7\%) content. The pretreated solids allowed for high saccharification yields, of up to $68 \%$ with low enzyme load and full hydrolysis when enzyme load increased. Finally, use of the pretreated solids as raw material for high-gravity fermentation resulted in an ethanol titer of $80 \mathrm{~g} / \mathrm{L}$.

\section{Methods}

\section{Feedstock}

In the present work, wood chips from silver birch (Betula pendula L.) originating from mills in Northern Sweden were used. Bark-free chips were air-dried and milled in a Retsch SM 300 knife mill (Retsch GmbH, Haan, Germany) through a 1-mm screen and used for the pretreatment experiments. The composition of untreated birch (expressed in dry basis) was $34.7 \% \mathrm{w} / \mathrm{w}$ cellulose, $31.2 \% \mathrm{w} / \mathrm{w}$ hemicellulose, and $18.7 \% \mathrm{w} / \mathrm{w}$ lignin. The moisture of the chips used during the experiments was $6.0 \% \mathrm{w} / \mathrm{w}$.

\section{Pretreatment}

All pretreatment experiments were performed in a horizontal configuration steam explosion reactor modified to operate in organosolv mode [26] (Fig. 7). In short, the apparatus consists of a steam generator, a steam explosion reactor with a discharge valve through which the pretreatment liquor is discharged to a cyclone and finally into a collection vessel, a blowout tank that allows the removal of excess steam condensate generated in the main reactor, and a pump that allows introduction of the organosolv solvent into the reactor. The biomass was manually introduced inside the reactor in a batch mode ( $200 \mathrm{~g}$ of milled birch chips that were mixed with $400 \mathrm{~g}$ of ethanol containing the acid catalyst (where applicable), were used per batch of pretreatment). After loading the 'wet' biomass, the remainder of the solvent (ethanol) amount was added into the reactor by an external pump to achieve the desired ethanol content of the liquor during pretreatment. Heating of the reactor at the desired temperature was achieved with a combination of steam (internally) and electrical heating elements (externally on the reactor). The introduction of steam as well as the removal of condensate and liquor was controlled by electronically operated valves, except for the discharge valve which

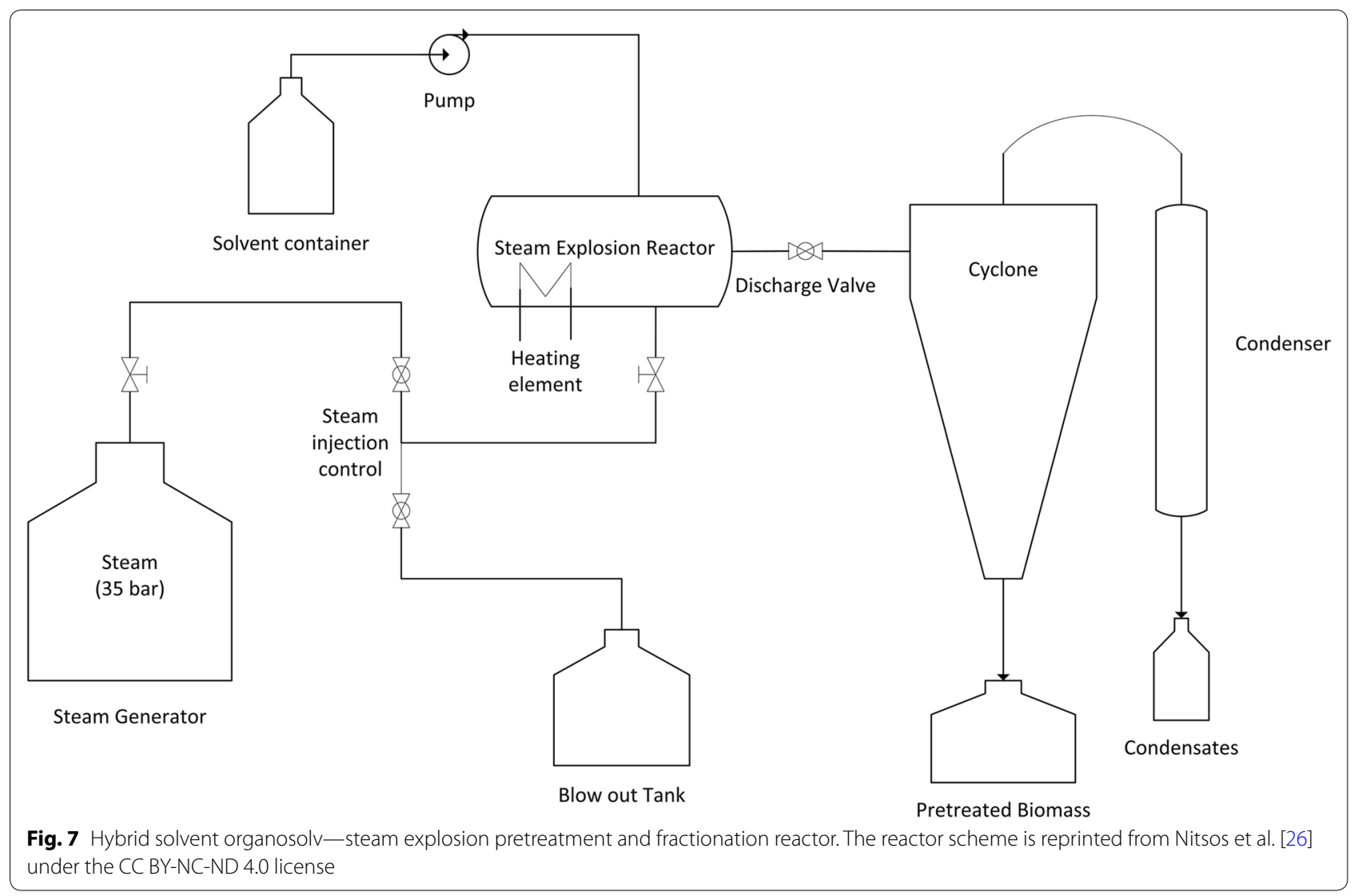


was operated manually. At the end of the pretreatment time, the discharge valve was opened, and the pretreatment slurry was exploded through the cyclone and into the collection vessel (see Fig. 7 for a schematic representation of the rector). During the hybrid organosolvsteam explosion trials, the effect of ethanol content $(50-70 \% \mathrm{v} / \mathrm{v}$ of the pretreatment liquor), treatment duration (15-60 min), and addition of acid catalyst (sulfuric acid; $0-1 \% \mathrm{w} / \mathrm{w}_{\text {biomass }}$ ) were evaluated under a constant treatment temperature of $200{ }^{\circ} \mathrm{C}$. The solubilization of the main biomass components (cellulose, hemicellulose, and lignin) in the pretreated liquor at the end of the pretreatment was calculated using the following equation

$$
\begin{aligned}
& \text { Component solubilization }(\% \mathrm{w} / \mathrm{w}) \\
& \qquad=100 \times\left(\frac{W_{\text {untreat }} \times C_{\text {untreat }}-W_{\text {pretreat }} \times C_{\text {pretreat }}}{W_{\text {untreat }} \times C_{\text {untreat }}}\right),
\end{aligned}
$$

where $W_{\text {untreat }}$ and $W_{\text {pretreat }}$ represent the weights (in grams) of initial untreated solids and of the recovered pretreated solids after the pretreatment, respectively, expressed in dry basis. $C_{\text {untreat }}$ and $C_{\text {pretreat }}$ are the contents $(\% \mathrm{w} / \mathrm{w})$ of the biomass component (cellulose, hemicellulose, or lignin) for the untreated and pretreated biomass, respectively.

Control experiments were performed in the same reactor to determine the effect of solvent pretreatment and of explosive decompression of the pretreatment slurry. These included steam explosion pretreatment, steam non-explosion pretreatment, and organosolv non-explosion pretreatment. Specifically, organosolv non-explosion experiments were performed in the same way as hybrid organosolv-steam explosion with one difference: at the end of the pretreatment time, the discharge valve was not opened. Instead, the valve to the blowout tank was opened, allowing removal of the liquor into the blowout tank and a gradual reduction of pressure; thus avoiding the explosion of the biomass that remained inside the reactor. After removal of the liquid through the valve, the reactor lid was opened, and the pretreated biomass was manually collected from the reactor. The organosolv non-explosion pretreatment was performed at the optimal conditions obtained in the current work, without the addition of the acidic catalyst to better study the effect of the explosion step. Steam explosion experiments $\left(200{ }^{\circ} \mathrm{C}\right.$ for $5 \mathrm{~min}$ with $0.14 \% \mathrm{w} / \mathrm{w} \mathrm{H}_{2} \mathrm{SO}_{4}$ ) were performed as previously described [26]. Steam non-explosion experiments were performed by the removal of pretreatment liquid into the blowout tank via the respective valve and the manual collection of biomass from the reactor (as previously described for the organosolv non-explosion pretreatment).

\section{Lignin recovery}

After the organosolv-steam explosion experiment, the pretreatment slurry was vacuum-filtered to separate the solids from the liquor. Ethanol was removed from the liquor in a rotary evaporator to reduce lignin solubility. Lignin was finally isolated by centrifugation $\left(14,000 \mathrm{rpm}, 29,416 \times g\right.$, at $4{ }^{\circ} \mathrm{C}$ for $\left.15 \mathrm{~min}\right)$, air-dried, and analyzed for its purity (composition in carbohydrates and ash-see "Chemical analysis" section). The clear liquor obtained after centrifugation and containing solubilized sugars was collected for sugars determination. Pretreated biomass solids were washed with ethanol to remove surface-bound lignin, air-dried, and stored until further use.

In the steam pretreatment experiments, lignin was not isolated, but the liquid and solid fractions were separated by vacuum filtration, and the solids were washed with deionized water until a neutral $\mathrm{pH}$ of the filtrate was achieved.

\section{Chemical analysis}

Analysis of the chemical compositions of untreated and pretreated solid biomass was performed as described elsewhere [58]. Carbohydrates were determined by HPLC analysis employing an Aminex HPX-87P column (BioRad, Hercules, CA, USA), with a column temperature of $85{ }^{\circ} \mathrm{C}, \mathrm{H}_{2} \mathrm{O}$ as mobile phase at a flow of $0.6 \mathrm{~mL} /$ min, and an RI (refractive index) detector. Acetyl groups were determined by measuring acetic acid with an Aminex HPX-87H column (BioRad, Hercules, CA, USA), $5 \mathrm{mM} \mathrm{H}_{2} \mathrm{SO}_{4}$ as mobile phase at a flow of $0.6 \mathrm{~mL} / \mathrm{min}$, and $65{ }^{\circ} \mathrm{C}$. To determine inorganic ash, samples were ashed at $550{ }^{\circ} \mathrm{C}$ for $3 \mathrm{~h}$ to remove any organic content and the ash was determined gravimetrically. To determine carbohydrate and ash contents in recovered lignin, samples underwent the same procedure as pretreated solid biomass. The same HPLC method as above was used to calculate sugar monomers in pretreatment liquid. To determine sugar oligomers, concentrated sulfuric acid was added to liquid samples to a final concentration of $4 \%$, samples were hydrolyzed at $121{ }^{\circ} \mathrm{C}$ for $1 \mathrm{~h}$, and then neutralized, filtrated, and analyzed as described above. Ethanol produced during fermentation was analyzed on an Aminex HPX-87H column using the conditions described before. Biomass moisture content was analyzed with a Sartorius MA 30 (Sartorius AG, Goettingen, Germany) moisture analyzer. 


\section{SEM analysis}

Samples were prepared by mounting them on conducting carbon tapes. They were imaged with a scanning electron microscope (JEOL 7800-F Prime) in low vacuum (100 Pa) and high vacuum $\left(10^{-4} \mathrm{~Pa}\right.$ or lower), with an acceleration voltage of $3.0 \mathrm{kV}$. To image the samples in high vacuum, and therefore increase image resolution, a thin coating with palladium was performed. A layer of a few nanometers increased the conductivity sufficiently to image in high vacuum. Images in low vacuum and high vacuum were compared to ensure that the coating did not affect sample morphology.

\section{Enzymatic hydrolysis trials}

Enzymatic hydrolysis tests were performed on pretreated biomass samples to establish their enzymatic saccharification yield and test the efficiency of the pretreatment method. Hydrolysis was performed in cotton-stoppered 100-mL flasks with a dry matter content of $2 \%(\mathrm{w} / \mathrm{v})$, a final volume of $40 \mathrm{~mL}$, and $50 \mathrm{mM}$ citrate buffer at $\mathrm{pH} 4.8$ using the commercial enzyme solution Cellic ${ }^{\circledR}$ CTec2 (Novozymes A/S, Bagsværd, Denmark) which has an enzyme activity of $149 \mathrm{FPU} / \mathrm{g}$ [50]. During the initial trials, we screened the birch biomass obtained using various pretreatment conditions with 6 FPU of enzyme loading per gram of solids. Enzyme dosage tests on the most promising material were carried out with 6,12 , and $22.5 \mathrm{FPU} / \mathrm{g}$ solids. Flasks were incubated in a shaken water bath (OLS 200, Grant Instruments, Cambridge, UK), at $120 \mathrm{rpm}$ (orbital arm of $9 \mathrm{~mm}$ radius) for $48 \mathrm{~h}$ at $50{ }^{\circ} \mathrm{C}$. All experiments were performed in duplicate. Samples obtained before and after hydrolysis (at 0 and $48 \mathrm{~h}$ ) were filtered through $0.2-\mu \mathrm{m}$ nylon syringe-filters and stored at $-20{ }^{\circ} \mathrm{C}$ until further analysis. Glucose released during hydrolysis was determined using HPLC as described previously [59]. Saccharification yield was defined as

$$
\eta=100 *\left(\frac{C_{\text {glucose }} * V_{\text {liquid }} * 0.90}{m_{\text {solids }} * x_{\text {cellulose }}}\right),
$$

where $C_{\text {glucose }}$ is the concentration of glucose measured by HPLC in $\mathrm{g} / \mathrm{L}, V_{\text {liquid }}$ is the volume of the liquid used in the hydrolysis, 0.90 is the correction factor for the addition of a molecule of water during the hydrolytic reaction, $x_{\text {cellulose }}$ is the mass fraction of cellulose in dry solids, and $m_{\text {solids }}$ is the mass of the dry solids. The results of the saccharification yield are based on the cellulose content of the pretreated solids.

\section{Ethanol fermentation trial at low solid concentration}

For SSF (simultaneous saccharification and fermentation) at low gravity, samples pretreated with $(60 \%$ ethanol, $\left.1 \% \mathrm{H}_{2} \mathrm{SO}_{4}, 15 \mathrm{~min}\right)$ and without acid catalyst $(60 \%$ ethanol, $60 \mathrm{~min}$ ) were used. As the saccharification yield among non-acid-treated samples was the highest for a 60-min treatment, we used this condition rather than the 15-min one. Biomass was prehydrolyzed for $8 \mathrm{~h}$ with $6 \% \mathrm{w} / \mathrm{w}$ solids and then diluted to $5 \% \mathrm{w} / \mathrm{w}$ with the addition of Saccharomyces cerevisiae Ethanol $\operatorname{Red}^{\circledR}$ and nutrients $\left(1 \mathrm{~g} / \mathrm{L}\right.$ yeast extract, $0.5 \mathrm{~g} / \mathrm{L}\left(\mathrm{NH}_{4}\right)_{2} \mathrm{HPO}_{4}$, and $\left.0.025 \mathrm{~g} / \mathrm{L} \mathrm{MgSO}_{4} .7 \mathrm{H}_{2} \mathrm{O}\right)$ for a pitching load of $20 \mathrm{mg}$ dry cell matter/g solids. Samples were taken every $24 \mathrm{~h}$ over 5 days for ethanol measurement. They were centrifuged, the supernatant was filtered through a $0.2-\mu$ m nylon filter, and analyzed by HPLC as described before. Fermentations were performed in duplicates.

\section{High-gravity ethanol fermentation}

During high-gravity fermentation, birch pretreated for 15 min with $60 \%$ ethanol (v/v) and $1 \% \mathrm{H}_{2} \mathrm{SO}_{4}(\mathrm{w} / \mathrm{w})$ was used. Saccharification took place in a gravimetric saccharification chamber as described previously [47, 48]. Pretreated birch biomass was saccharified at a dry material content of $20 \% \mathrm{w} / \mathrm{w}$ in citrate buffer $(50 \mathrm{mM})$ with 18.5 FPU of Cellic ${ }^{\circledR}$ CTec2 per gram of solids. Saccharification took place at $50{ }^{\circ} \mathrm{C}$ for $8 \mathrm{~h}$, after which the slurry was collected and used for SSF. The slurry was supplemented with nutrients to achieve a final concentration of $1 \mathrm{~g} / \mathrm{L}$ yeast extract, $0.5 \mathrm{~g} / \mathrm{L}\left(\mathrm{NH}_{4}\right)_{2} \mathrm{HPO}_{4}$, and $0.025 \mathrm{~g} / \mathrm{L}$ $\mathrm{MgSO}_{4} \cdot 7 \mathrm{H}_{2} \mathrm{O}$ from a concentrated stock solution so that the volume change after addition was $<2 \%(\mathrm{v} / \mathrm{v})$. The SSF experiment was initiated by addition of $S$. cerevisiae Ethanol $\operatorname{Red}^{\circledR}$ suspension (from an overnight YPD culture grown in $250 \mathrm{~mL}$ flasks at $35^{\circ} \mathrm{C}$ and $180 \mathrm{rpm}$ ) amounting to an initial cell concentration of $1 \mathrm{~g} / \mathrm{L}$ dry cell matter. Samples were taken regularly throughout the cultivations, which were performed in duplicates at $35{ }^{\circ} \mathrm{C}$ and $120 \mathrm{rpm}$. Samples were diluted five times based on mass, filtered through a $0.2-\mu \mathrm{m}$ nylon filter, and analyzed by HPLC as described in the chemical analysis section.

\footnotetext{
Authors' contributions

LM: participated in the experimental design and data analysis, performed the pretreatments, participated in the analysis of the recovered fraction and in high-gravity fermentation, and drafted the manuscript. CN: participated in experimental design and data analysis and drafted the manuscript. VR: performed enzymatic hydrolysis of pretreated samples and SSF at low- and high-gravity, and wrote parts of the manuscript. OY: performed the pretreatments and analyzed the recovered fractions. GP: performed SEM analysis. EO: analyzed SEM pictures. UR: conceived the study and participated in experimental design and data analysis. LO: conceived the study and participated in experimental design and data analysis. PC: conceived the study and participated in experimental design and data analysis. All authors read and approved the final manuscript.
} 


\begin{abstract}
Author details
1 Biochemical Process Engineering, Division of Chemical Engineering, Department of Civil, Environmental, and Natural Resources Engineering, Luleå University of Technology, 971-87 Luleå, Sweden. ${ }^{2}$ Division of Industrial Biotechnology, Department of Biology and Biological Engineering, Chalmers University of Technology, Kemivägen 10, 41296 Göteborg, Sweden. ${ }^{3}$ Department of Physics, Chalmers University of Technology, Fysikgränd 3, 41296 Göteborg Sweden. ${ }^{4}$ Present Address: Department of Molecular Biology and Biotechnology, University of Sheffield, Sheffield S10 2TN, UK.
\end{abstract}

\section{Acknowledgements}

The authors would like to thank Sveaskog, Sweden, for providing the birch chips; Novozymes A/S, Denmark, for providing the Cellic ${ }^{\circledR}$ CTec2 enzyme solution; and Lesaffre Advanced Fermentations, France, for providing the Ethanol $\operatorname{Red}^{\circledR}$ that were used during this work.

\section{Competing interests}

The authors declare that they have no competing interests.

\section{Availability of data and materials}

The materials produced during the current study are available from the corresponding author on reasonable request.

\section{Consent for publication}

Not applicable.

\section{Ethics approval and consent to participate}

Not applicable.

\section{Funding}

This work was funded by Swedish Energy Agency as part of the SolveFuels project (funded by Swedish Energy Agency). Leonidas Matsakas, Ulrika Rova, and Paul Christakopoulos thank Bio4Energy, a strategic research environment appointed by the Swedish government, and Kempe Foundations, for supporting this work. Vijayendran Raghavendran and Lisbeth Olsson thank Chalmers Area of Advance Energy for financial support via the strategic research environment funding.

\section{Publisher's Note}

Springer Nature remains neutral with regard to jurisdictional claims in published maps and institutional affiliations.

Received: 30 March 2018 Accepted: 1 June 2018

Published online: 08 June 2018

\section{References}

1. Menon V, Rao M. Trends in bioconversion of lignocellulose: biofuels, platform chemicals and biorefinery concept. Prog Energy Combust Sci. 2012;38:522-50.

2. Zhao X, Zhang L, Liu D. Biomass recalcitrance. Part I: the chemical compositions and physical structures affecting the enzymatic hydrolysis of lignocellulose. Biofuels Bioprod Biorefin. 2012;6:465-82.

3. Haghighi Mood S, Hossein Golfeshan A, Tabatabaei M, Salehi Jouzani G, Najafi GH, Gholami M, et al. Lignocellulosic biomass to bioethanol, a comprehensive review with a focus on pretreatment. Renew Sustain Energy Rev. 2013;27:77-93.

4. Kumar P, Barrett DM, Delwiche MJ, Stroeve P. Methods for pretreatment of lignocellulosic biomass for efficient hydrolysis and biofuel production. Ind Eng Chem Res. 2009;48:3713-29.

5. Eklund $\mathrm{R}$, Galbe $\mathrm{M}$, Zacchi $\mathrm{G}$. The influence of $\mathrm{SO}_{2}$ and $\mathrm{H}_{2} \mathrm{SO}_{4}$ impregnation of willow prior to steam pretreatment. Bioresour Technol. 1995:52:225-9.

6. Torget RW, Kim JS, Lee YY. Fundamental aspects of dilute acid hydrolysis/ fractionation kinetics of hardwood carbohydrates. 1. Cellulose hydrolysis. Ind Eng Chem Res. 2000;39:2817-25.

7. Nitsos CK, Matis KA, Triantafyllidis KS. Optimization of hydrothermal pretreatment of lignocellulosic biomass in the bioethanol production process. Chemsuschem. 2013;6:110-22.
8. Pielhop T, Larrazábal GO, Studer MH, Brethauer S, Seidel C-M, Rudolf von Rohr P. Lignin repolymerisation in spruce autohydrolysis pretreatment increases cellulase deactivation. Green Chem. 2015;17:3521-32.

9. Monavari S, Bennato A, Galbe M, Zacchi G. Improved one-step steam pretreatment of SO2-impregnated softwood with time-dependent temperature profile for ethanol production. Biotechnol Prog. 2010;26:1054-60.

10. Tu M, Chandra RP, Saddler JN. Evaluating the distribution of cellulases and the recycling of free cellulases during the hydrolysis of lignocellulosic substrates. Biotechnol Prog. 2007;23:398-406.

11. Bozell JJ. An evolution from pretreatment to fractionation will enable successful development of the integrated biorefinery. BioResources. 2010;5:1326-7.

12. Öhgren K, Bengtsson O, Gorwa-Grauslund MF, Galbe M, Hahn-Hägerdal B, Zacchi G. Simultaneous saccharification and co-fermentation of glucose and xylose in steam-pretreated corn stover at high fiber content with Saccharomyces cerevisiae TMB3400. J Biotechnol. 2006;126:488-98.

13. Eriksson G, Kjellström B, Lundqvist B, Paulrud S. Combustion of wood hydrolysis residue in a 150 kW powder burner. Fuel. 2004;83:1635-41.

14. Cherubini F. The biorefinery concept: using biomass instead of oil for producing energy and chemicals. Energy Convers Manag. 2010;51:1412-21.

15. Isikgor FH, Becer CR. Lignocellulosic biomass: a sustainable platform for the production of bio-based chemicals and polymers. Polym Chem. 2015;6:4497-559.

16. Ragauskas AJ, Beckham GT, Biddy MJ, Chandra R, Chen F, Davis MF, et al. Lignin valorization: improving lignin processing in the biorefinery. Science. 2014;344:1246843.

17. Saini JK, Patel AK, Adsul M, Singhania RR. Cellulase adsorption on lignin: a roadblock for economic hydrolysis of biomass. Renew Energy. 2016;98:29-42.

18. Nitsos C, Rova U, Christakopoulos P. Organosolv fractionation of softwood biomass for biofuel and biorefinery applications. Energies. 2018;11:50.

19. Nitsos C, Stoklosa R, Karnaouri A, Vörös D, Lange H, Hodge D, et al. Isolation and characterization of organosolv and alkaline lignins from hardwood and softwood biomass. ACS Sustain Chem Eng. 2016;4:5181-93.

20. Park N, Kim HY, Koo BW, Yeo H, Choi IG. Organosolv pretreatment with various catalysts for enhancing enzymatic hydrolysis of pitch pine (Pinus rigida). Bioresour Technol. 2010;101:7046-53.

21. Matsakas L, Nitsos C, Vörös D, Rova U, Christakopoulos P. High-titer methane from organosolv-pretreated spruce and birch. Energies. 2017;10:263.

22. Duff SJB, Murray WD. Bioconversion of forest products industry waste cellulosics to fuel ethanol: a review. Bioresour Technol. 1996;55:1-33.

23. Zhao X, Cheng K, Liu D. Organosolv pretreatment of lignocellulosic biomass for enzymatic hydrolysis. Appl Microbiol Biotechnol. 2009;82:815-27.

24. Hongzhang C, Liying L. Unpolluted fractionation of wheat straw by steam explosion and ethanol extraction. Bioresour Technol. 2007;98:666-76.

25. Maniet G, Schmetz Q, Jacquet N, Temmerman M, Gofflot S, Richel A. Effect of steam explosion treatment on chemical composition and characteristic of organosolv fescue lignin. Ind Crops Prod. 2017;99:79-85.

26. Nitsos C, Matsakas L, Triantafyllidis K, Rova U, Christakopoulos P. Investigation of different pretreatment methods of Mediterranean-type ecosystem agricultural residues: characterisation of pretreatment products, high-solids enzymatic hydrolysis and bioethanol production. Biofuels. 2017. https://doi.org/10.1080/17597269.2017.1378988.

27. Pan X, Gilkes N, Kadla J, Pye K, Saka S, Gregg D, et al. Bioconversion of hybrid poplar to ethanol and co-products using an organosolv fractionation process: optimization of process yields. Biotechnol Bioeng. 2006;94:851-61.

28. Huijgen WJJ, Telysheva G, Arshanitsa A, Gosselink RJA, de Wild PJ. Characteristics of wheat straw lignins from ethanol-based organosolv treatment. Ind Crops Prod. 2014;59:85-95.

29. Zhang Z, Harrison MD, Rackemann DW, Doherty WOS, O'Hara IM. Organosolv pretreatment of plant biomass for enhanced enzymatic saccharification. Green Chem. 2016;18:360-81.

30. Ma $X$, Yang $X$, Zheng $X$, Chen $L$, Huang $L$, Cao $S$, et al. Toward a further understanding of hydrothermally pretreated holocellulose and isolated pseudo lignin. Cellulose. 2015;22:1687-96.

31. Bensah EC, Mensah M. Chemical pretreatment methods for the production of cellulosic ethanol: technologies and innovations. Int J Chem Eng. 2013;2013:1-21. 
32. Sun $S L$, Sun $S N$, Wen JL, Zhang XM, Peng F, Sun RC. Assessment of integrated process based on hydrothermal and alkaline treatments for enzymatic saccharification of sweet sorghum stems. Bioresour Technol. 2015;175:473-9.

33. Kumar R, Hu F, Sannigrahi P, Jung S, Ragauskas AJ, Wyman CE. Carbohydrate derived-pseudo-lignin can retard cellulose biological conversion. Biotechnol Bioeng. 2013;110:737-53.

34. Verdía P, Brandt A, Hallett JP, Ray MJ, Welton T. Fractionation of lignocellulosic biomass with the ionic liquid 1-butylimidazolium hydrogen sulfate. Green Chem. 2014;16:1617.

35. Sturgeon MR, Kim S, Lawrence K, Paton RS, Chmely SC, Nimlos M, et al. A mechanistic investigation of acid-catalyzed cleavage of aryl-ether linkages: implications for lignin depolymerization in acidic environments. ACS Sustain Chem Eng. 2014;2:472-85.

36. Kobayashi T, Kohn B, Holmes L, Faulkner R, Davis M, Maclel GE. Molecularlevel consequences of biomass pretreatment by dilute sulfuric acid at various temperatures. Energy Fuels. 2011;25:1790-7.

37. Sannigrahi P, Ragauskas AJ, Miller SJ. Lignin structural modifications resulting from ethanol organosolv treatment of loblolly pine. Energy Fuels. 2010;24:683-9.

38. Huijgen WJJ, Reith JH, Den Uil H. Pretreatment and fractionation of wheat straw by an acetone-based organosolv process. Ind Eng Chem Res. 2010;49:10132-40.

39. Ruiz HA, Vicente AA, Teixeira JA. Kinetic modeling of enzymatic saccharification using wheat straw pretreated under autohydrolysis and organosolv process. Ind Crops Prod. 2012;36:100-7.

40. Ximenes E, Kim Y, Ladisch MR. Biological conversation of plants to fuels and chemicals and the effects of inhibitors. In: Wyman CE, editor. Aqueous pretreatment of plant biomass for biological and chemical conversion to fuels and chemicals. Chichester: Wiley; 2013. p. 39-60.

41. Pan X, Xie D, Yu RW, Lam D, Saddler JN. Pretreatment of Lodgepole pine killed by mountain pine beetle using the ethanol organosolv process: fractionation and process optimization. Ind Eng Chem Res. 2007:46:2609-17.

42. Pereira Ramos $L$. The chemistry involved in the steam treatment of lignocellulosic materials. Quim Nova. 2003;26:863-71.

43. Seidel C-M, Pielhop T, Studer MH, Rudolf Von Rohr P. The influence of the explosive decompression in steam-explosion pretreatment on the enzymatic digestibility of different biomasses. Faraday Discuss. 2017;202:269-80.

44. Pielhop T, Amgarten J, von Rohr PR, Studer MH. Steam explosion pretreatment of softwood: the effect of the explosive decompression on enzymatic digestibility. Biotechnol Biofuels. 2016;9:152.

45. Zacchi $G$, Axelsson A. Economic evaluation of preconcentration in production of ethanol from dilute sugar solutions. Biotechnol Bioeng. 1989;34:223-33.
46. Koppram R, Tomás-Pejó E, Xiros C, Olsson L. Lignocellulosic ethanol production at high-gravity: challenges and perspectives. Trends Biotechnol. 2014:32:46-53.

47. Matsakas L, Christakopoulos P. Fermentation of liquefacted hydrothermally pretreated sweet sorghum bagasse to ethanol at high-solids content. Bioresour Technol. 2013;127:202-8.

48. Matsakas L, Kekos D, Loizidou M, Christakopoulos P. Utilization of household food waste for the production of ethanol at high dry material content. Biotechnol Biofuels. 2014:7:4

49. Katsimpouras C, Zacharopoulou M, Matsakas L, Rova U, Christakopoulos P. Topakas E. Sequential high gravity ethanol fermentation and anaerobic digestion of steam explosion and organosolv pretreated corn stover. Bioresour Technol. 2017;244:1129-36.

50. Wang R, Koppram R, Olsson L, Franzén CJ. Kinetic modeling of multi-feed simultaneous saccharification and co-fermentation of pretreated birch to ethanol. Bioresour Technol. 2014;172:303-11.

51. Koppram R, Olsson L. Combined substrate, enzyme and yeast feed in simultaneous saccharification and fermentation allow bioethanol production from pretreated spruce biomass at high solids loadings. Biotechnol Biofuels. 2014:7:54.

52. Yáñez-S M, Rojas J, Castro J, Ragauskas A, Baeza J, Freer J. Fuel ethanol production from Eucalyptus globulus wood by autocatalized organosolv pretreatment ethanol-water and SSF. J Chem Technol Biotechnol. 2013;88:39-48

53. Bertilsson M, Olofsson K, Lidén G. Prefermentation improves xylose utilization in simultaneous saccharification and co-fermentation of pretreated spruce. Biotechnol Biofuels. 2009:2:8.

54. Frankó B, Galbe M, Wallberg O. Influence of bark on fuel ethanol production from steam-pretreated spruce. Biotechnol Biofuels. 2015;8:15.

55. Dong C, Wang Y, Zhang H, Leu SY. Feasibility of high-concentration cellulosic bioethanol production from undetoxified whole Monterey pine slurry. Bioresour Technol. 2018;250:102-9.

56. Katsimpouras C, Kalogiannis KG, Kalogianni A, Lappas AA, Topakas E. Production of high concentrated cellulosic ethanol by acetone/water oxidized pretreated beech wood. Biotechnol Biofuels. 2017;10:54.

57. Ramachandriya KD, Wilkins M, Atiyeh HK, Dunford NT, Hiziroglu S. Effect of high dry solids loading on enzymatic hydrolysis of acid bisulfite pretreated Eastern redcedar. Bioresour Technol. 2013;147:168-76.

58. Sluiter A, Hames B, Ruiz R, Scarlata C, Sluiter J, Templeton D, et al. NREL/ TP-510-42618 analytical procedure-determination of structural carbohydrates and lignin in biomass. Lab Anal Proced. 2012;1617:17.

59. Koppram R, Mapelli V, Albers E, Olsson L. The presence of pretreated lignocellulosic solids from birch during saccharomyces cerevisiae fermentations leads to increased tolerance to inhibitors - a proteomic study of the effects. PLoS ONE. 2016;11:e0148635.
Ready to submit your research? Choose BMC and benefit from:

- fast, convenient online submission

- thorough peer review by experienced researchers in your field

- rapid publication on acceptance

- support for research data, including large and complex data types

- gold Open Access which fosters wider collaboration and increased citations

- maximum visibility for your research: over $100 \mathrm{M}$ website views per year

At BMC, research is always in progress.

Learn more biomedcentral.com/submissions 